\title{
Kenteoretiese besinning oor teologiebeoefening aan die 'Teologiese Skool van Potchefstroom die afgelope twintig jaar
}

\author{
Gerrie Snyman \\ Departement Ou Testament \\ UNISA \\ PRETORIA
}

\begin{abstract}
In commemoration of the death a hundred ycars ago of Dirk Postma, the founding faiher of the (ierefonnerde Kerke in South Africa, this article focuses on the theological creativity of the past twenty years at the Theological School in Potchefstroom. Theological creativity in the GKSA should be viewed in the light of a fear of humanism, horizontalism and secularism. In the chunches' zealousness to treat the Bible as the Word of God, in order to be able to say 'Thus says the Lord God', the need to reflect on the recipients' epistemological presuppositions is not felt. Consequcntly, Ncoplatonism, Positivism and Naive Realism found their way into the theological activity of the TSP. A lack of such refection on these epistemological presuppositions creates the possibility of projecting them back into the Bible and then investing them with rctelational authority.
\end{abstract}

\section{INLEIDING}

\author{
...wat is dic mens dan dat $U$ aan hom dink, \\ die mensckind dat $U$ na hom omsien? \\ $U$ het hom net 'n bictjic minder \\ as ' $n$ hemelse wesc gemaak \\ en hom met aansien en ecr gekroon, \\ $\mathrm{U}$ laat hom hecrs oor dic werk van u hande, \\ U het alles aan hom onderwerp: ...
}

Psalm 8, 'n loflied oor die skepping, verskaf 'n positiewe beeld van die mens. Die optinisme oor die mens hou verband met die posisie wat die mens as homo artifex of homo partificiens ten opsigte van die skepping gekry het: met die status van net 'n bietjie minder as 'n goddelike wese ontvang die mens die opdrag om die tuin te bewerk en daaroor te heers. Aan die eerste mense was dit 'n geleentheid om skeppend besig te kon raak en die moontlikheid te kon ontgin om self aan die skepping deel te neem. Met die verhaal van die sondeval word hierdie moontlikheid nie uitgewis nie. Wanneer God die eerste twee mense uit die paradys jaag, verloor nie een van hulle hulle

1 Hierdic artikel is 'n verwerking van 'n lesing wat gelewer is in Junic 1990 op 'n Postma. dagseminaar by dic Universiteit van Suid-Afrika. 
kreatiewe vermoëns nie. Die enigste verskil is dat die kreatiwiteit van daardie oomblik af met moeite en risiko gepaardgegaan het. Sedertdien moes die mens, letterlik gesproke, 'n lewe in hierdie wêreld uitbeitel.

Dit is belangrik om die kreatiewe vermoëns van die mens, asook die moeite waarmee dit gepaardgaan, in gedagte te hou wanneer besin word oor teologiese besigwees in die kerke in Suid-Afrika. Om meer spesifiek te wees, die aanloop en uiteindelike stigting van die Gereformeerde Kerke in Suid-Afrika (GKSA) in 1859 is 'n goeie voorbeeld van hoe lewe op kerklike terrein uitgebeitel is nadat ervaar is dat ander beitels nie gewerk het nie. Die moeite en verdriet waarmee die verwisseling van beitels gepaardgegaan het, spreek uit die skeuring wat gevolg het.

Nou, nadat ons in 1990 die dood (honderd jaar gelede) van Dirk Postma herdenk het en hom erken as dié een wat onmiskenbaar tot die lewe van die Gereformeerde Kerke in Suid-Afrika bygedra het, is die GKSA (saam met al die ander kerke in die RSA) nog steeds besig om ' $n$ lewe op Suid-Afrikaanse grondbodem uit te beitel. Die situasie het intussen verander, want die pad wat nou oopgekap moet word, hang saam met 'n nuwe politieke bestel. Ook hierdie proses gaan op die oomblik gepaard met moeite en seerkry, veral as mens kyk na lidmate se reaksies op dit wat op die oomblik in die GKSA aangaan. Dit lyk so asof die beitels wat gebruik word net nie meer geskik is om die werk te doen nie (vgl. P.P. Krüger 1991a:29; 1991b; Snyman, 1991:10-12, M.A. Kruger, 1991:25; G.J. Kruger 1991:6; Schutte, 1991:7; Van der Linde, 1991:10 en Fourie, 1991:28). Vir baie mense het die GKSA irrelevant begin word. Ilet die kerke se beitels nie dalk stomp of selfs onbruikbaar geraak nie?

Hierdie artikel sal nie waag om op laasgenoemde vraag uitsluitsel te gee nie. Wat op die oomblik nodiger skyn te wees, is om na beitels te kyk waarmee tans in die GKSA gewerk word. Daar is uiteraard verskeie stelle beitels vir die verskillende paadjies wat die GKSA moet oopkap, maar 'n spesifieke stel is dié wat gebruik word om op akademiese gebied 'n plekkie vir die GKSA skoon te maak. Ilierdie artikel wil 'n haie spesifieke stel 'beitels' onder die vergrootglas sit, naamlik daardie kenteoretiese vooronderstellings wat teologievorming beïnvloed. Die standpunt is dat daar ' duidelike verband te trek is tussen teologiese arbeid en bepaalde kenteoretiese vooronderstellings. Na my beste wete is daar egter nêrens duidelik onskryf wat presies die kenteoretiese vooronderstellings is waarmee teologie in die GKSA bedryf word nie. Hierdie artikel is 'n poging om na die aard en 'funksies' van die kenteoretiese beitels binne die GKSA te kyk.

\section{NOOIDSAAK VAN KIINTEORITTIISE BESINNINC;}

In die verlede het die andag nogal talamlik skerp geval op die handelsmerk van die beitels wat gebruik word, dit wil sê die Gereformeerde tradisie waaruit die GKSA kom 
(vgl. P.J. Coetzee, 1979:6). Tog is gemeen (Coetzee, 1979:7) dat dié handelsmerk in die toekoms al hoe skaarser gaan word, omdat Gereformeerde teoloë ervaar het dat die 'suiwer Skriftururlike gereformeerde teologie' besig was om 'n al hoe eensamer pad te loop omdat teologie besmet word met ander handelsmerke, soos mensgesentreerdheid, horisontahisme en sekularisme (vgl. ook P.J. Coetzee, 1977:5). As teenvoeter is in die laat tagtigerjare die klem laat val op bewaring, behoud en getrouheid aan die handelsmerk waaraan daar - om die woorde van D'Assonville (1986:6) 'n bietjie uit verband te gebruik - die reuk van martelaarsvure nog kleef.

Vrees vir mensgesentreerdheid, horisontalisme en sekularisme het op een of ander wyse daartoe bygedra dat die erkenning van die rol wat kenteoretiese vooronderstellings in die GKS^ se teologicse besigwees speel, nog agterweë gebly het. Ilierdie vrees skyn gegrond te wees op 'n vermeende gevaar dat dit wat geglo word van God afkomstig is en dit wat die mens doen, vermeng kan raak. Gevolglik moet teologiese besigwees aan die menslike werklikheid ontruk word en as 'n teologiese askese beoefen word. Hierdic indruk word deur Venter (1989:175) geskep wanneer hy die mening uitspreek dat (binne die GKSA) teologiebeoefening met sy "Skrif-gefiltreerde vitsprake" nie met dieselfde gesag en geldigheid beklee kan word as wetenskapsfilosofiese debatvoering nie. Volgens hom is dit onregverdig om uitsprake wat net klankbord probeer wees van God se openbaring aan dieselfde maatstawwe te meet as "die spekulatiewe denkteorieë van die ekumeniese teologie" (oftewel, die nuwere teologiese ontwikkelings). Met hierdie argument word dit wat die mens dink, eenvoudig vereenselwig met spekulasies, terwyl dit wat gemeen word dat God in die Bybel sou sè, as die enige en ewige waarheid, bo alle spekulasie verhewe is. Venter (1989:176) sien nie 'n rede hockom tcologic in die GKSA die rasionele arena hoef tc betree nie: "Dit is en bly die Gees wat die onvervalsde warheid van God aan die mens openbaar, en dit is die Gees wat dwing tot gehoorsaamheid." Die rol wat aan die lleilige Gees toegeken word, maak rasioncle modelle oorbodig.

Die implikasic is dat reformatoriese teologie (wat te make het mel die kennis wat vir die saligheid nodig is) nie nodig het om te verantwoord op die wetenskapsfilosofiese terrein nie, omdat dit nog altyd maar net antwoorde bied uit God se Woord aan dié wat dit as gesagvol aanvaar (vgl. Venter, 1989:176). In die lesingsaal sowel as van die kansel moet gesê kan word: So sê die Here HERE. Daar is uiteindelik geen verskil tussen 'n teologies-wetenskaplike artikel en 'n preek nie! Hierdie byna anti-intellektuele denkwyse word beaam deur 'n briefskrywer aan Die Kerkblad (De Beer, 1990:3031). De Beer maak beswaar teen predikante, professore en teologiese studente wat onder die naam van wetenskaplik verantwoordhare denke hulleself sckere vryhede ten opsigte van hulle siening sou eis. Hy beskou hierdie vryheid as die oorsaak van 'verwarring' onder lidmate. Om die verwarring stop te sit, mag die wetenskaplike verantwoording nie verhewe bo kerke gestel word nie. Die implikasie van hierdie 
gedagte moet skrikwekkend wees vir enige teoloog wat binne 'n tersiêre opset akademikus wil wees, want nou word die legitimiteit van hulle uitsprake nie gemeet in terme van maatstawwe wat pas by akademiese inrigtings nie (soos denkraamwerke), maar in terme van ongereflekteerde denke van die gewone lidmaat vir wie ander kriteria geld.

Die gedagte dat teologie net klankbord moet wees van God se Woord, is egter'n eerlike poging om 'suiwer' met die Bybel as Woord van God besig te wees. As God in die Bybel spreek, dan moet die mens - wat inherent boos is - homself probeer ontdoen van hierdie remming ten einde die Woord suiwer te hoor. 'Suiwer' beteken hier: sonder enige invloed van buite. Die doel daarvan is om te kan sé: So sê die HERE Here. So 'n uitspraak is egter reeds swaar belaai met 'n bepaalde wetenskapsfilosofiese heskouing!

Die uitgangspunt van hierdie artikel is dat dit ommoontlik is om sonder ' $n$ wetenskapsfilosofie reologies besig te wees. Dat 'n mens so iets gebruik, is ook nie verkeerd nie! Calvyn en Luther het baie geput uit die ou Griekse filosowe, soos Plato en Aristoteles. 'n Duidelike verdiskontering van kenteoretiese vertrekpunte bied aan lesers 'n raamwerk waarbinne hulle iemand se denke kan plaas. As elkeen sy eic raamwerk op die tafel plaas, dan is dit makliker om agter te kom waarom mense verskil. 'n Debat is dan ook meer sinvol en nie so bitter nie. Wyle prof. Fanus du Toit (1966:62) het al erken dat logika en kenteoretiese oorwegings 'n rol in die teologie hehoort te speel. Die erkenning van 'n hesondere kenteoretiese heskouing maak dit moontlik om die mens se rol in teologiese kennisvorming te verdiskonteer.

Om die rol van kenteorie in die Gereformeerde teologie uit te wys, mag dalk uiters gewaagd wees, want kenteorie maak dat mens nie meer so 'suiwer' hoor nie. Erger nog, die uitspel van 'n kenteoretiese vertrekpunt bring Gereformeerde teologie in die rasionele arena. Vanuit 'n resepsie-teoretiese raamwerk kan nie meer gesê word dat mense bloot moet hoor, dit wil sê, sonder enige remmings op die kommunikasieproses nie. 'Klankbord-eksegese' veronderstel 'n passiewe resepsie in dieselfde $\sin$ as wat Thomas Aquinas dit in sy Summa Theologiae (1a.75.5) gestel het, byna soos 'n spons wat water absorbeer. Daarteenoor moet gestel word dat die lees van tekste (Bybels én nie-Bybels) van lesers 'n transformering vereis in hulle gedagtes aangalnde dit wat in die tekste staan. Die Bybelteks wat hetrokkenheid, gevoel en refleksie (cf Iloltz, 1984:28) vra, word indenwaarheid herskryf.

Omdat lesers van mekaar verskil in terme van persoonlikhede, situasies en kultuur, word dieselfde teks verskillend gelees. Verskillende lesings is nie maar net te wyte aan die sondige gebrokenheid van die mens wat nie die een warheid van (iod kan vasvat nie, maar is inderwaarheid geleë in die feit dat dieselfde teks vanuit verskillende kontekste gelees word. Die GKSA is malar een konteks walarbinne die Bybel gelees 
word. Terselffertyd bestaan hierdie konteks uit snitte van ander kontekste, soos 'n bepaalde sosiologiesc konteks wat dui op 'n blanke middelklaskerk, 'n bepaalde politicke konteks waar spanning ervaar word ten opsigte van menseverhoudings in die land, en 'n bepaalde kenteoretiese konteks van waaruit sekere waarheidsaansprake ten opsigte van die Bybel gemaak word. Dit is lasgenoende konteks wat vir die huidige gesprek van belang is.

Ondat hierdie artikel doelbewus sekere aspekte na vore bring wat deur sommige Gereformeerdes as vreemd ervaar sou word, moet vooraf gestel word dat die uitwys van sekere wetenskapsfilosofiese elcmente nie op 'n negatiewe etikettering neerkom van daardie persone by wie se standpunte die elemente gevind word nie. Die woorde van 'n voormalige rektor van die 'Teologicse Skool op Potchefstroom in die begin van die sewentigerjare, wat op daardie stadium 'n tydperk van vernuwing by die TSP ingelui het deurdat die opleidingsraamwerk geherstruktureer is en nuwe dosente na die aftrede van ouer dosentc begin doseer het, is net so gepas as nou: hulle is "manne wat gedien het [en] wat geweldig baie vir Skool en Kerk beteken het" (Van der Walt, 1973:9). Die uitwys van wetenskapsfilosofiese elemente is eerder 'n eerlike poging om uit tc vind hoe die Bybelteks wat as vlas en koring tot die mens kom, uiteindelik deur Gereformeerde teoloě in brood en klere omgesit word.

Volgens 'n ou klassieke midrash wat deur Elia Zuta aangehaal word en wat sterk herinner aan die gelykenis van die tien talente (vgl. Braude \& Kapstein, 1981:407-408), het 'n koning op reis gegaan, maar vooraf aan wee van sy slawe vir wie hy baie lief was, elk 'n emmer koring en 'n bol vlas gegee. Die een het die bol vlas in 'n doek geweef, die koring gemalal en 'n brood gebak. Toe het hy die brood in die doek toegedraai. Dic ander slaaf het niks gedoen nie. Nodeloos om te sè watter slaaf guns in die koning se oë gevind het.

Die strekking van die gelykenis fokus nie op die twee slawe nie, mar op die koring en die vlas as simbool van die Tora wat in ruwe vorm tot Israel gekom het. Die koring en die vlas is egter met behulp van die Mishna tot 'n brood en 'n doek omvorm. Die Tora is die teks self en die Mishna dic verklaring van die teks. Dieselfde allegorie kan vandag gebruik word om die lees van die Bybel te illustreer: die koring en die vlas is die teks van die Bybel wat deur die Gereformeerde teoloë deur middel van preke in voedsel en klere vir die Gereformeerde lidmate omgevorm word. Die vraag is egter hoe dic Gereformeerde teoloë hicrdie koring en vlas omvorm.

Op gevaar af om te verooreenvoudig, word uitgegaan van die standpunt dat die tcologiese besigwees in die GKSA, veral soos dit bedryf word aan dic Teologiese Skool op Potchefstroom (as die sentrum van skeppende teologievorming binne die strukture van die GKSA), trekke toon van 'n Platonistiese denkwyse, 'n positivistiese denkmodel en 
'n naïef-realistiese benadering ten opsigte van die lees van die Bybelteks. Trekke van 'n Platonistiese denkpatroon kom na vore in die wyse waarop die mens in sy teologiese besigwees op die agtergrond geskuif word. Samehangend hiermee is die soeke na objektiwiteit 'n kenmerk van 'n positivistiese omgang met die Bybel. Die klem op objektiwiteit hang op sy beurt weer saam met'n naïewe realisme waarvolgens waarheid in terme van 'n korrespondensiemodel beskou word.

\section{PI ATONISTIESE INVIOED?}

Die probleem wat hier aangespreek word, is of die opsyskuiwing van die mens nie 'n Platonistiese of Neo-Platonistiese ondertoon het nle. Die opsyskuiwing van die mens kom sterk na vore in die hermeneutiek van J.C. Coetzee wie se beskouing polemies gesien moet word met W.S. Vorster se intreerede by Unisa se Instituut vir Teologiese Navorsing. J.C. Coetzee (1979:8) se verwyt teen Vorster is dat hy die Bybel wil lees soos sekulêre literatuur. Hieragter sien hy 'n bepaalde Skrifbeskouing wat dui op 'n beweging van die mens na God toe, sodat die Bybel gesien behoort te word as tekste oor God, 'n boek van benede gerig op dit wat daarbo is.

In teenstelling hiermee wil Coetzee 'n Skrifbeskouing formuleer aan hand van God w'at Homself in en deur die Bybel op ' $n$ bepaalde wyse kommunikeer. Hy (1984:19) formuleer dit later so:

Die Heilige Skrif bied aan ons die spreke van God se kant fol mense; nic die praat van mense oor God nie. In hierdie proses bied dic Skrifte ons primér spreke van (jod oor God tot mense.

Met ander woorde, God kommunikeer in die Bybel en lly doen dit deur tot mense te spreek. Wat Hy kommunikeer, is Homself. Die wyse waarop Ily dit doen, is deur mense. Die gebruik van mense dui vir Coetzee daarop dat die boek nie klaar uit die hemel geval het nie. Die Bybel het self 'n geskiedenis en dit handel eweneens oor hoe God Ilom in die geskiedenis geopenbaar het. Op grond hiervan kom hy (1984:19) tot 'n inspirasie-teorie wat hy, by gebrek aan 'n beter term, organiese inspirasie noem:

Ons bely dus dat die Bybcl, geskrywe deur mense van verskillende tye, agtergronde, gelecrdhede (wat ook duidelik in hulle geskrifte spreek), in die sin wel 'n $100 \%$ menslike bock is, maar deur die inspirasie van die Heilige Gees (...) is God die eintlike Skrywer, en is die Skrif tegelyk en in dic EERSTE PLEK $100 \%$ 'n Goddelike bock.

'n Besondere negatiewe opvatting oor die mens blyk uit die formulering van bogenoemde 'organiese inspirasie': dit is asof God en mens op so 'n wyse teenoor mekaar gestel word dat God eenvoudig moet wen. God verkry die 'eerste plek' terwyl die mens noodwendig die tweede plek inneem. Die menslike element word op die ou end deur die goddelikheid van die inspirasie in die agtergrond geskuif. Die rol wat uiteindelik aan God toegeken word, veroorsaak dat die Bybel nie as gewone menslike (sekulêre?) literatuur gelees word nie, maar as goddelike literatuur. 
Die implikasie van Jie 'organiese inspirasie' is volgens Coetzee (1984:19-20) die volgende: as God spreek, het die mens geen ander keuse as om te luister en te gehoorsaam nie, want in die Bybel is God self aan die woord. Ondat God aan die woord is, is kommunikasie nie 'n probleem nie. Voigens J.C. Coetzee (1979:13) sal kommunikasie alleen 'n probleenı wees vir diegene wat die Bybel as gewone literatuur beskou.

Hoewel dié inspirasiebeskouing getuig van 'n Calvinistiese vroomheid jeens God wat altyd voorop gestel word, het die beskouing ' $n$ ernstige implikasie wat die 'organiese' aard wat daaraan toegedig word, nutteloos maak: die fokus weg van die mens impliseer dat, indien die mens wel regstreeks aan die woord sou wees in die Bybel, dit moeiliker sou wees om die stem van God te hoor en te gehoorsaan. Word die mens nie té leuenagtig beskou nie sodat hy op die ou end alleen 'n meganiese rol te speel het in die teboekstelling van dit wat as die Bybel geken word? Indien die antwoord positief is, dan vertoon hierdie benadering in 'n sekere sin 'n sterk Platonistiese trek ten opsigte van die mens se deelname aan die skryf en lees van die Bybel.

In sy boek oor die staat (Politeius 2. 377 e.v., vgl. De Win, 1980) het Plato nogal baie te sê oor mense wat as 'digters' dit gewaag het om oor die gode te skryf. Sy sensuur van die werke van Homeros sentreer rondom drie kernelemente van sy filosofiese raamwerk: god is die outeur van dit wat goed is; daar is by hom 'n onveranderlikheid en hy vertel geen leuens nic (vgl. Shorey, 1938:65). Die sensuur wat Plato voorstel, beteken dat die verhale wat aan kinders vertel word, eers gekeur behoort te word, omdat die skrywers (veral Homeros en llesiodos) as 'samestellers van leuenverhale' beskou word.

Met leuenverhale bedoel Plato dat hierdie digters ' $n$ verkeerde beeld gee van die helde en die gode. Hy vergelyk hulle skrywe met 'n skilder wat 'n portret maak wat min ooreenkons toon met die beeld wat hy wil afbeeld. Die gebrek aan duidelike korrespondensie maak hierdie verhale verwerplike 'leuenverhale'. Die gode word byvoorbeeld te menslik voorgestel, omdat hulle as oorlogsugtiges geteken word. Terselfdertyd meen die digters dat goed én kwaad van die gode afkomstig is, terwyl Plato, deur middel van 'n ingewikkelde redenasie, meen dat die gode net goed kan doen. Om kwaad aan die gode toe te dig, is nie vroom nie en boonop vir die samelewing nutteloos. Dié soort leuens word deur die mens en deur die gode verfoei (Politeias, 2.382). Hierteenoor stel Plato alles wat bonatuurlik of van die gode afkomstig is vry van leuens. God kan nie lieg nie. Die digters veroorsaak dat die mense dink dat gode lieg, en dit kon Plato nie duld nie, omdat sulke stellings nie godsvrug in die hand werk nie (vgl. ook Else, 1986:19-22).

Plato se siening oor die digters moet gesien word in terme van die raamwerk van sy kentcorie (vgl. Stumpf, 1975:52-65). Hy onderskei tussen 'n sigbare wêreld en 'n 
waardig beskou teenoor die kennis wat in die verstaanbare wêreld verkry word. Alleen in laasgenoemde wêreld is ware kennis te vinde. Die vorme in hierdie wêreld is abstraksies van werklike objekte wat deur die verstand in alle suiwerheid hanteer kan word, sonder enige inmenging van een of ander simbool van die sigbare objek.

Volgens Plato vind die mees oppervlakkige vorm van kennisverwerwing plaas deur middel van beelde en verbeelding, dit wil sê standbeelde, skilderye en gedigte of verhale. Beelde wat minstens twee trappe van die werklikheid verwyder is, byvoorbeeld ' $n$ borsbeeld van Sokrates, verwys eerstens na die vorm van die ideale man, dan na 'n idee van hoe Sokrates self gelyk het. Fisies is dit egter net 'n borsbeeld van Sokrates wat by die aanskouer allerhande drogbeelde oproep (Politeias 3. 386 e.v.).

Vanuit 'n Platonistiese oogpunt kan die mens nie alleen die verantwoordelikheid dra vir die skryf van die Bybel nie, omdat die mens as 'digter' net lewens vertel. As die Bybel van mense afkomstig moet wees, boet dit in aan waarheidskrag, want die mens is nie in staat om self iets sinnigs oor God te sề nie. Maar selfs al sou aan die mens verantwoordelikheid vir die Bybel toegeken word, is die implikasie dat daar net oppervlakkig oor God gesels kan word, want die mens word gereken as iemand wat nie in staat is om die waarheid te vertel of vas te vat nie. Waarheid is universeel en geniet voorrang bo die beperktheid van die mens. Dit is hierdie beperktheid wat die mens noop om leuens te vertel. 'n Mens kan maar net fiksie skep. Binne so 'n Platonistiese raamwerk maak Coetzee se Skrifbeskouing sin.

Plato het sy siening in die Christelike tradisie laat geld, veral in die tyd van die kerkvaders. Volgens Tigerstedt (1974:7) is Platonisme in die eerste drie eeue van die Christelike jaartelling omvorm tot 'n metafisiese of teologiese sisteem. Dit was maklik om binne hierdie klimaat Platonisme as 'n voorbereidling van die evangelie te sien. Jauß (1982:92) maak die opmerking dat veral die heidense kuns in daardie tyd as onwaar beskou is en tot die werk van die duiwel gedegradeer is. Die heidense kuns het die vroeë Christene afvallig gemaak en die kerkvaders het daardie afval bestry. Een van die maniere was om die Griekse veelgodedom te verchristelik - standbeelde van die Griekse gode is byvoorbeeld vervang met Christelike simbole (vgl. Metzler, 1973:26).

Die kerkvaders staan binne die raamwerk van die Neo-Platonisme. Met Neo-Platonisme word daardie filosofiese sisteem verstaan wat met Plotinos se resepsie van Plato begin het en die bril geword het waarmee kerkvaders, veral Augustinus (cf Tigerstedt, 1974:10), teologie bedryf het. Van hierdie gedagtes het later via Calvyn in gereformeerde (en ook Gereformeerde) teologie hulle weg gevind.

Volgens Plotinos (vgl. Stumpf, 1975:129-135) is die stoflike wêrelı! geensins met die ware werklikheid te vereenselwig nie, in dié sin dat die stoflike wèreld veranderlik is 
terwyl die 'ware' onveranderlik moet wees. God is onveranderlik; daarom moet Hy die 'waarheid' wees. Maar dit lyk of Plotinos homself in 'n hoek bevind, want as God die onveranderlike is, beteken dit dat God nie kan skep nie. Om te kan skep, impliseer volgens Plotinos verandering, iets wat God nie kan wees nie.

Om uit hierdie dilemma te kom, gebruik Plotinos onder andere die metafoor van 'uitstraling'. Soos die son lig uitstraal, so is God die bron van alles. Waar die lig die naaste aan die son die helderste is, so is die verstand (nous) die hoogste vorm van bestaan, omdat dit die naaste aan die bron is. Hoe verder die son is, hoe flouer is die lig, en hoe minder volmaak is die opvolgende 'dinge'. Die laagste vlak in Plotinos se hiërargie is die stoflike wêreld, wat die menslike liggaam insluit. Hier het mens eintlik met duisternis as die teenpool van lig te doen. Dit is hier waar kwaad ontstaan, omdat dit die verste grens is van die bron. Tog beteken 'kwaad' nie dat iemand anders met God in kompetisie is nie, mar impliseer dit eerder net die afwesigheid van volmaaktheid of orde.

Die hiërargiese synswyses impliseer dat die een synswyse aanleiding gee tot die volgende een. God gee aanleiding tot die nous; die siel gee aanleiding tot die stoflike liggaam. Omdat die beweging altyd weg van die bron is, het die stoflike liggaam die neiging om ook verder van die siel te beweeg. Binne die denkraamwerk van Plotinos beteken dit dat die stoflike liggaam van die rasionaliteit van die siel na irrasionaliteit beweeg. Op hierdie vlak word die liggaam deur allerhande emosies aangedryf. Kwaad ontstaan in die verskil tussen die siel se regte bedoelings en die liggaam se werklike (irrasionele) gedrag.

Hoewel Coetzee sekerlik nie as 'n Platonis beskou moet word nie, vertoon die Skrifbeskouing wat hy voorstaan Platonistiese elemente in die mate wat die mens in die Skrifbeskouing gesensureer word. Dit is alleen binne 'n (Neo)-Platonistiese raamwerk dat mens en God met mekaar in kompetisie tree en dat God noodwendig moet wen. God is die bron van alles maar die mens neig weg van Hom af. Die mens is nie volmaak nie. Voeg hierby Plato se afkeer van die digters wat net leuens oor gode kan vertel. Op grond van hierdie siening kan die mens nie een goeie woord oor God sê nie; hy kan net sê wat die bron, dit wil sê God self, aan hom sê.

Binne 'n Gereformeerde raamwerk funksioneer hierdie denke in terme van 'n sondebeskouing waar die mens as so verdorwe geag word dat hy glad nie in staat is om enige goed te doen nie, tensy hy "wedergebore word deur die Heilige Gees" (Heidelbergse Kategismus, Antwoord 8). Mens en God moet by mekaar uitgebring word. Binne die Christendom word dit deur die Heilige Gees bewerkstellig. Binne die Neo-Platonisme gebeur dit wanneer God en mens verenig deurdat alles wat die mens van God kan weg- 
trek, vermy word, byvoorbeeld die stoflike materie moet nie die siel beïnvloed nie. Die pad na God is egter nie maklik nie, want tussen die liggaam (die stoflike materie) en die siel (die nous) woed 'n verbete stryd. Binne Plotinos se denke is daar 'n leer wat geklim moet word, iets wat sterk herinner aan die weg van heiligmaking binne die Calvinistiese godsdiens.

Die Neo-Platonistiese denke maak 'n duidelike onderskeid tussen die sekulêre en die 'goddelike' - 'n onderskeid wat sy invloed duidelik in teologiese denke laat geld, veral in die inspirasiebeskouing se literatuurbegrip. Hiervolgens kan die Bybel nie as gewone literatuur beskou word nie omdat dit dan binne die sfeer van die sekulêre wêreld sal val en 'n skrywer van die sekulêre wêreld kan nie waar van God praat nie vanweë verskeie remminge. Ten einde waarheid aan die Bybel te kan toedig, moet die Bybel verskuif word van die menslike arena na die goddelike sfeer waar God altyd aan die wenkant is. Die ondergeskikte posisie wat uiteindelik aan die mens as skrywer toegeken word, korrespondeer met die rol wat Plato aan die digter toeken: nie een is in staat om iets sinnigs oor God te skryf nie.

'n Mens kan sê bogenoemde vermeende invloed is baie simplisties aangebied en te meganies, 'n strooipop wat uiteindelik nie met Coetzee se benadering strook nie. Wat hier plaasgevind het, was net 'n poging om 'n filosofiese agtergrond vir 'n bepaalde benadering te postuleer, omdat dit nêrens uitgespel is nie. 'n Mens ontwerp nie altyd benaderings met 'n spesifieke filosofie in die agterkop nie. Die ontwikkeling van 'n benadering geskied meesal intuïtief binne 'n historiese werklikheid waar sekere elemente geselekteer en op 'n bepaalde wyse gekombineer word. Refleksie daaroor kom eers later wanneer ' $n$ kritiese afstand nodig geword het.

Omdat Platonisme en Neo-Platonisme deur teoloë met teologiese moedersmelk ingeneem word (Plato - Plotinos - Augustinus - Calvyn - ortodoksie - vandag), word daar nie meer daaroor nagedink nie. Plato se invloed moet egter nie onderskat word nie, want sy filosofie is nog deel van die Westerse beskawing. Solank as wat die Westerse beskawing bestaan, solank as wat teologie op 'n Westerse wyse beoefen word, en solank as wat die teoloë van die GKSA hulle nie losmaak van 'n Westerse leef- en denkwyse nie, solank sal Plato sy invloed op teologiese gebied laat geld. Nadenke oor filosofiese invloede het egter nou nodig geword, omdat die moontlikhede binne die GKSA groot is om deur middel van 'n openbaringspositivisme die filosofiese bril waarmee gelees word, met openbaringsgesag te beklee.

Die vermeende Platonistiese trekke hoef nie remmend of destruktief in die Gereformeerde teologiebeoefening te werk nie, want ander groot hermeneute steun ook op Plato, hoewel met ander interpretasies van sy filosofie. Selfs Gadamer, wat Heidegger se kunsfilosofie uitgebou het, steun in ander aspekte sterk op die filosofie van Plato 
(vgl. Jauß, 1982:96). Wat belangriker is, is dat daardie raamwerke erken moet word en nie in die geheim moet funksioneer nie.

Geen mens lees sonder een of ander filosofiese raamwerk nie. Tog word die gebruik van sulke raamwerke in sommige kringe nie duidelik uitgespel nie, uit vrees vir subjektiwisme. Die onderdrukking van sulke raamwerke in die leesproses van die Bybel hou verband met die onderbeklemtoning van die mens wie se verdorwe aard (hetsy as gevolg van die sonde of as gevolg van die neiging om altyd verder weg van die bron te beweeg) veroorsaak dat geen waarheid geheg kan word aan enige ervaring wat die mens opdoen nie.

\section{4. 'N POSITIVISIIESE ELEMENT?}

Die teenpool vir die vrees vir subjektiwisme word gevind in 'n positivistiese strewe om die Bybel so 'objektief as moontlik te lees. As aanvaar word dat God in die Bybel spreek, dan moet die mens - wat inherent boos is - homself ontdoen van remminge ten einde die Woord suiwer te hoor. Suiwer moet hier verstaan word in die sin van 'selfontlediging', dit wil sê sonder enige 'sondige' invloed van buite. Die doel daarvan is om te kan sê: So sê die IIERE Here.

F.N. Lion-Cachet (1984:42) neem artikel I van die Nederlandse Geloofsbelydenis as sy vertrekpunt. In hierdie geloofsartikel word die andersheid van God teenoor die mens gestel. Buiten dat hierdie geloofsartikel geweek is in Neo-Platonistiese denke, is een van die gevolgtrekkings wat Lion-Cachet hieruit maak die objektiwiteit en vastigheid van God teenoor die subjektiewe en die veranderlike by die mens. Dit beteken dat God in sy spreke tot die mens nie tydgebonde is nie en dat Hy mag spreek tot 'n universele gehoor.

By Lion-Cachet vind mens 'n poging om sy Skrifbeskouing op 'n wetenskaplike basis te stel, hoewel hy erken dat hy nie veel aptyt het vir' 'n kenteoretiese gesprek nie (cf LionCachet, 1985:45-48). Hy (1986:14) sien sy wetenskapsbeoefening as deskriptief van aard: "... die versameling, sistematisering, interpretering en kontrolering van kennis sodat algemeen geldende waarhede in God se algemene en besondere openbaring (...) tot eer van God beskyf kan word en tot nut van die mens aangewend kan word".

Hy vind steun in Cornelis van Til se openbaringsepistemologie. Van Til (1955:57) - en 'n mens wonder in watter mate Van Til nie ook deur Platonistiese denke beinvloed is nie - gaan uit van die gedagte dat kennis van God objektief moet wees. Daar is 'n wêreld van objekte wat deur die subjek met betrekking tot God verklaar moet word. Om enigsins ware kennis te hê, moet daar in God 'n absolute sisteem van kennis wees, sodat alles na daardie absolute sisteem herlei kan word (Van Til, 1955:61). Hieruit 
kan die volgende afgelei word: omdat die mens nie absoluut is nie, moet die begin buite hom gesoek word. Dit word gevind in die Woord van God wat heenwys na die absolute sisteem van God.

'n Positivistiese element kom baie sterk na vore in die oproep na objektiwiteit. Volgens 'n positivistiese denkmodel word kennis verkry deur objektiewe waarneming en in die objektiewe beskrywing van dit wat waargeneem word. Enige subjektiewe waarde-oordele is taboe (vgl. Köhn, 1975:34). 'n Baie belangrike kenmerk van positivisme ten opsigte van die lees van die Bybel is dat die teks gedefinieer word onafhanklik van die lesende subjek. Die leser word 'n blote waarnemer wat betekenis uit die teks moet tap (vgl. Deist, 1988:44). God het betekenis in die teks gedeponeer eens en vir altyd deur middel van 'n menslike skrywer. Betekenis lề in die teks, of anders gestel, die teks is 'n deposito van betekenis wat net metodies beskryf en verklaar hoef te word. Die lesers hoef maar net te sê wat God sè.

Nie alleen moet die Bybel 'n objek buite of los van die mens wees nie, maar die mens self moet hom of haar ontdoen van alle remminge wat sy of haar waarneming kan steur. Die wetenskaplike moet in staat wees om 'n proses waar te neem sonder dat hy of sy ingryp (op dieselfde wyse as 'n natuurwetenskaplike in 'n laboratorium wat ' $n$ eksperiment waarneem en kontroleer). Die wetenskaplike moet alleen maar beskryf en verklaar. Lion-Cachet se definisie van sy teologiese wetenskapsbeoefening verraai gevolglik sy positivistiese kenteoretiese raamwerk: hy wil net die waarhede aangaande God vanuit die Bybel besknf en verklaar. Op so 'n wyse word die mens se subjektiewe ervarings (die veranderlike element wat nie in die wetenskap toelaatbaar skyn te wees nie) 'vermy'.

Deur die Bybel as 'n objektiewe kenbron te hanteer, is dit maklik om die mens (as die een wat ken/lees) op die agtergrond te skuif. Te veel klem op die mens het die gevaar dat iemand van oewerlose subjektivisme beskuldig kan word. Selfs die hele leesproses en die epistemologiese begronding van 'n Skrifbeskouing word agterweë gelaat deurdat op 'n naief-realistiese wyse aanvaar word dat die mens in staat is om te lees sonder om enige aandeel in die leesproses te he. Die vraag is of die mens se subjektiewe ervarings weliswaar vermy kan (of behoort te) word en of hy nie die objek van waarneming, die Bybelteks, in alle geval versteur in die leesproses nie? Hoe is dit dan moontlik dat lesers 'n gedeelte in die Bybel op verskillende wyses interpreteer? Dit wil eerder voorkom of die subjektiewe inderdaad 'n groter en selfs primère rol speel in die leesproses. 'n Oewerlose subjektiwisme word juis veroorsaak wanneer die rol van subjektiewe elemente, soos kenteoretiese vertrekpunte, nie vooraf duidelik uitgestippel word nie. 


\section{NAİEWE REALISME}

Die onderwaardering van die mens as sou hy of sy te leuenagtig wees om self waarheid te kan genereer, die probleemloosheid van die kommunikasie tussen God en mens via die Bybel en die klem op 'n objektiewe beskrywing van die Bybel se betekenis wat deur God gedeponeer is, het tot ' $n$ situasie van naiewe realisme in die GKSA se teologiebeoefening gelei. Naïewe realisme is volgens Van Huyssteen (1987:19; eie vertaling GS)

... 'n denkmodel waarvolgens tcorieč gesien word as 'n akkurate beskrywing van dit waarna verwys word. Dic wêreld word beskou soos dit insigself is asof die wêreld van homself getuig.

J.N. Vorster (1988:158) praat hiervan as "die onmiddellikheid van kennis" en Blumenberg (1964:10) verwys hierna as die "Realität der momentanen Evidenz". Beide konsepte veronderstel 'n regstreekse verband tussen dit wat gebeur en die beskrywing daarvan deur 'n waarnemer; tussen die 'feit' en die konsep wat daarvan gevorm word; tussen die teorie en die werklikheid waarop die teorie betrekking het. Die teorie of die gevormule konsep staan in 'n een tot een korrespondensie met die gebeurtenis self, sodat waarheid en werklikheid een word. Die gevolg is dat die waarheid as werklikheid onweerlegbaar en onmiddellik geopenbaar word in die oomblik wat dit weergegee word. 'n Konsekwensie van dié onmiddelikheid van kennis is dat die resepsie daarvan nie 'n probleem word nie, want die weergawe word beskou as die akkurate beskrywing van die werklikheid.

Hierdie denkwyse kom sterk na vore in wat genoem word die openbaringshistoriese benadering wat as basiese denkmodel binne die GKSA dien en as die akkurate beskrywing van die werklikheid beskou word. Hierin het J.C. Coetzee met sy artikel saam met De Klerk en Floor (1980) en Helberg (1983) met sy boek oor die verklaring van die Ou Testament 'n groot aandeel. Die positivistiese raamwerk spreek duidelik wanneer hierdie benadering die klem op die 'selfgetuienis' van die Bybel as Skrif wil laat val. Wat sê die Bybel van sigself volgens hierdie model? Helberg (1983:61) sê die Bybel gee gesagvolle getuienis of openbaring van God se heerskappy en verlossende optrede in die verlede, hede en toekoms. Hiermee word nie alleen die teks van die Bybel die ontvanger van ' $n$ betekenis wat God deur 'n menslike skrywer daarin gedeponeer het nie, maar die teks kan onafhanklik van die mens as leser iets sê, sodat die mens maar net die 'boodskap' moet aanvaar. Boonop word hierdie model naïf-realisties aangewend: by bykans geen navolger van die openbaringshistoriese benadering (Lion-Cachet in 'n sekere mate uitgesluit) sal mens 'n kritiese refleksie oor die kenteoretiese agtergrond van die benadering vind nie.

Die probleem lê in die begrip van selfgetuienis van die Bybel. As die Bybel self 'getuig', en daarby 'n goddelike boek is, dan is kritiese refleksie oor die Bybel en sy herkoms in alle geval oorbodig. Dit sou dalk selfs op ongehoorsaamheid neerkom, want dit wat God in die Bybel gee, word dan bevraagteken. Binne hierdie raamwerk kan die Bybel tog nie in die beskuldigdebank geplaas word nie. 
Die Bybel bied egter geen selfgetuienis sonder dat dit ' $n$ antwoord is op ' $n$ bepaalde vraag nie. Hierdie vrae word geformuleer deur mense wat in 'n bepaalde konteks leef en self bepaalde probleme probeer aanspreek. Wanneer die Bybel vanuit 'n openbaringshistoriese raamwerk aanvaar word as 'n bron wat die historiese werklikheid weergee, dan is dit nie omdat die Bybel self so getuig nie, maar eerder omdat die lesers met 'n naief-realistiese konsep van geskiedskrywing te werk gaan en daaruit historiese vrae aan die Bybel vra.

Die naïef-realistiese konsep van geskiedskrywing word gestimuleer deur 'n geskiedenisbeskouing wat verband hou met 'n korrespondensiemodel van waarheid. Volgens die model is alles wat geskryf is, waar, want dit het so gebeur (cf Botha, 1990:10). Binne so 'n model is kommunikasie ook nie 'n probleem nie, want die mens moet net lees wat geskryf staan.

Dit is hier waar Plato homself wreek. Plato het nie die skrywers of digters se weergawes van gebeure onder die gode aanvaar nie. Om waarheid in terme van korrespondensie te sien, sou beteken dat Plato die digters se 'leuens' as waarheid moes aanvaar. Cancik (1970:34-45) noem egter die bevraagtekening van die digters se verhale Mythenkritik. Hiervolgens is die ou Griekse skrywers nie altyd op gesigswaarde aanvaar asof hulle verhale die weergawe van die werklike gebeure verteenwoordig nie. Die gevolg was dat die digters altyd maar probeer het om die ou Griekse mites meer geloofwaardig te maak (Cancik, 1970:41); hulle self het nie aanvaar wat die vroeëre digters gesê het nie. Daar is voortdurend nuwe verhale geskryf en dié voortdurende verandering het Plato skynbaar genoop om die digters se verhale af te wys as veranderlik en onstabiel. Geen mens kan op 'n veranderlikheid staatmaak nie. Die mense moes iets hê wat konstant is en derhalwe waar is.

Dié soort Mythenkritik word egter in beginsel nie op die Bybel toegepas nie, omdat aan die Bybel 'n goddelike karakter toegeskryf word. Die gevolg hiervan is dat alles wat in die Bybel staan, op gesigswaarde aanvaar moet word as waarheid én die werklike gebeure. Tog vind Mythenkritik wel onder die skrywers van die Bybel plaas. Die Kronis vertel nie alles wat in die Samuelboeke geskryf staan nie; hy vervorm die verhaal om dit vir sy eie gemeenskap meer geloofwaardig te maak. Dieselfde het gebeur met die vier Evangelies: elkeen vertel die verhaal van Christus, maar op so 'n wyse dat dit vir die gemeenskap vir wie dit bedoel is, gelonfwaardig kon wees.

Vanweë 'n ongereflekteerde korrespondensiemodel van waarheid waarmee die openbaringshistoriese benadering werk, word die Bybel gelees as sou dit summiere getuienis wees van God se daadwerklike optrede in die wêreld. Daarom ' $n$ vind mens ook 
die argument dat indien mense moet aanvaar dat 'n sekere gebeurtenis wat in die Bybel vertel word, nie in werklikheid plaasgevind het nie, dan kan die Bybel nie meer geglo word nie (vgl. C.F.C. Coetzee, 1989). Baie mense meen dat indien Jona 'n fiktiewe persoon was, dan beteken die werk van Christus niks nie, want albei moet op historiese werklikhede berus om geglo te kan word. Dat Jona (as fiktiewe verhaal) dalk eerder in Aristoteliaanse sin verwys na dit wat moontlik is en nie na 'n historiese feitelikheid nie, kan nie vanuit 'n 'openbaringshistoriese' benadering aanvaar word nie, omdat dié benadering, vanweë 'n naïef-realistiese wêreldbeeld, nie ruimte laat vir 'n metaforiese gesigspunt nie. Op hierdie wyse verkry alles in die Bybel dieselfde feitelike status: grammatika, geskiedenis, natuurwetenskaplike elemente, kulturele agtergrond en religieuse elemente word op een vlak gestel met gelyke status (vgl. Vorster, 1988:162).

Indien die mens alleen maar hoef te beskryf wat in die Bybel gevind word, moet hy dit op die een of ander manier wel verstaan. Floor koppel om hierdie rede die selfgetuienis van die Bybel aan die Heilige Gees wat aan die mens sekere dinge duidelik maak sodat hy kan verstaan. Dat hulp uit 'n 'ander oord' ingeroep moet word om verstaan moontlik te maak, is 'n aanduiding dat 'kommunikasie' nie so probleemloos geskied nie. Floor (1980:13) probeer die probleem oplos deur die klem op die Heilige Gees te laat val. 'n Mens kry egter die indruk dat die Heilige Gees as 'n soort skuiling teen 'n rasionele verklaring vir ' $n$ bepaalde leeswyse dien, want wie durf teen 'n beroep op die Heilige Gees stry?

Floor steun baie sterk op Calvyn, maar Calvyn het nie 'n uitgewerkte metode van Bybellees daargestel nie - hy was 'n kind van sy tyd en gevolglik deurdrenk van die filologiese metodes waarmee in daardie tyd na antieke geskrifte toe gegaan is. 'n Mens wonder in watter mate die Calvinistiese denke nie hier deur 'n Neo-Platonistiese verwysingsraamwerk beinvloed is nie. Binne die Neo-Platonisme kan die mens net doen wat reg is wanneer hy of sy met god verenig is. Dit lyk of die Heilige Gees 'n Neo-Platonistiese vereniging met God moontlik maak, sodat die mens kan weet wat God se wil in die Bybel is.

Hoe diep die naief-realistiese benadering reeds in die Gereformeerde teologiebeoefening gewortel is, blyk uit die gebruik of toepassing van die beginsel van die deursigtigheid van die Skrif. Hierdie beginsel beteken vir J.C. Coetzee nie dat die Bybel vir elkeen verstaanbaar en duidelik is nie, maar wel dat die Skrif genoegsaam duidelik is dat enige redelike mens duidelik genoeg die boodskap van redding kan hoor en tot geloof in Jesus Christus mag kom (J.C. Coetzee, 1982:8), met ander woorde, die deursigtigheid moet gesien word in terme van geloof en saligheid. Hierdie soort lees moet egter gesien word in terme van 'n "kinderlik-gelowige" lees van die Bybel (vgl. J.C. Coetzee, 1981:10), omdat geglo word dat God eerder aan kindertjies dinge geopenbaar het as aan wyse mense (vgl. Venter, 1989:164 na aanleiding van Matt. 11:25). 
Die koppeling van so 'n tipe Bybellees met die deursigtigheid van die Bybel maak egter amok (vgl. Venter, 1989:170) wanneer dit op teologiese wetenskapbeoefening van toepassing gemaak word, deurdat die geldigheid van ander Skrifbeskouings betwis word bloot omdat dit spanning en onsekerheid by gewone lidmate wek. 'n Mens kry werklik die idee dat die beoefening van teologie alleen sin het as dit vir die kinderlik-gelowige lidmaat bevatlik is en dit nie sy verwysingsraamwerk deurmekaar skud nie.

Die effek van die naiewe realisme op Gereformeerde teologiebeoefening het gemaak dat Bybellees probleemloos, konteksloos, onkrities moet plaasvind deurdat 'n wetenskaplike ondersoek na die bestaan, die aard en herkoms van 'n uitspraak in die Bybel oor die werklikheid as ontoelaatbaar beskou is. Dit het gebeur toe prof. J.J.J. van Rensburg onder andere aangekla is omdat hy die deursigtigheid van die Skrif 'aantas' deurdat hy gebruik gemaak het van die boek I llenog in sy verklaring van wat Petrus bedoel het met die uitdrukking geeste in die gevangenis in 1 Petrus 3:19 (cf Van Rensburg, 1989:18).

Van Rensburg wou die identiteit van die geeste in die gevangenis waarvan in 1 Petrus 3:19 sprake is, bepaal. Nadat hy na 2 Petrus 2:4 en Judas 6 verwys het, waar daar sprake is van engele wat aan God ongehoorsaam was en wat in alle waarskynlikheid op dieselfde gebeure in die tyd van Noag sou verwys het, meen Van Rensburg dat die apokriewe boek van 1 Henog hierdie vermoede bevestig (Van Rensburg, 1988:64-65). Hy meen egter dat dit nog spekulatief is om geeste hier met engele te vereenselwig, omdat daar nie elders in die Bybel duidelik sprake is van engele wat in die tyd van Noag aan God ongehoorsaam was nie. Hy vind egter in die boek I Henog 'n bewys dat geeste as 'engele' geinterpreteer kan word. Van Rensburg meen dat die apokriewe boek I Henog as 'finale grond' vir die interpretasie van geeste as engele in 1 Petrus 3:19 (Van Rensburg, 1988:65) kan dien. Laasgenoemde boek gee 'n detailbeskrywing oor wat in die tyd van Noag sou gebeur het. Dit bied verder ook opvallende ooreenkomste met 1 en 2 Petrus en Judas asook agtergrondinligting wat kan help met die verstaan van wat die betrokke outeurs bedoel het en wat die eerste lesers waarskynlik verstaan het toe hulle die boeke gelees het. Van Rensburg meen dan dat die skrywer van die boek Petrus asook die lesers die boek Henog moes geken het, sodat hy tot die gevolgtrekking kom dat die interpretasie van geeste in 1 Petrus 3:19 gesien moet word as engele. Hy meen dat die skrywer van die boek Petrus "die gemeenskaplike kennis van hom en sy eerste lesers in verband met die engele wat in Noag se tyd gesondig het, [gebruik het], om vir sy eerste lesers te verduidelik dat Christus ook oor die slegte engele oorwin het en dat hulle geen bedreiging meer inhou nie" (Van Rensburg, 1988:66 - sy kursivering).

D'Assonville (1989:18-19) is van Inening dat, op grond van Artikel 6 van die Nederlandse Geloofsbelydenis, 'n apokriewe of pseudogeskrif nooit die 'finale' gesagvolle 
verklaring vir die Bybel kan wees nie. Teenoor Van Rensburg se omskrywing van geeste as engele, meen D'Assonville dat waar die Bybel nie meer die finale toets is nie, maar die onegte I lenog, 'n vreemde gebruik van die gereformeerde metode van Skrifverklaring plaasvind. Hyself sien die geeste as mense wat ongehoorsaam was in die tyd van Noag. 'n Mens wonder wel in watter mate 'n naïef-realistiese lees van I Petrus 3:19 by hom voorkom. Wat wel duidelik is, is dat sy gebruik van die hermeneutiese stelreël van perspecuitas van die Skrif naïef-realisties is. Artikel 6 van die NGB wat aan hierdie stelreël gekoppel word, en wat eintlik op die vlak van die geloof lê, word nou skielik as 'n toetssteen aangelê op die vlak van taaluiting. Geloof, linguistiese oorwegings en die pragmatiek word nou alles op een vlak ongenuanseerd gebruik.

\section{BEOORDELING VAN DIE IAASTE IWINTIG JAAR}

Die GKSA se teologiese besigwees die afgelope twintig jaar staan in 'n sekere sin in 'n spanning met die positiewe beoordeling van die mens in Psalm 8 . Hoewel die mens 'n kreatiewe taak gegee is, word die menslike kreatiwiteit in teologievorming tog onderspeel in die sin dat daar geen refleksie oor die mens se aandeel in die lees van die Bybel plaasgevind het nie. Dat Bybellees 'n vorm van kennisverwerwing is wat met moeite en risiko gepaardgaan, word deur 'n naiewe realisme getemper, deurdat kritiese refleksie op die 'beitels' waarmee gelees of verstaan word, nie bevorder word nie. Kyk 'n mens na die beitel waarmee D'Assonville sy besware teen J.J.J. van Rensburg se siening oor 1 Petrus 3:19 gevorm het, dan wonder mens of dié soort beitel nie inderdaad stomp geword het nie.

Wanneer 'n mens die teologiese besigwees binne die Gereformeerde Kerke vergelyk met die ontwikkeling binne die literatuurwetenskap, dan is dit opmerklik dat die teologie nog in die eerste twee fases is van die ontwikkeling van outeur - teks - leser (vgl. Lategan, 1988). Binne die literatuurwetenskap het daar 'n verskuiwing plaasgevind vanaf 'n genetiese benadering wat die skrywer en die ontstaanstyd bestudeer, via 'n teksgerigte benadering waartydens veral die strukturalisme hoogty gevier het na 'n lesersgeöriënteerde benadering waar die klem val op die rol van die leser in die hele leesproses.

Die klem by die GKSA se teologisering val nog sterk op God as outeur en op die Bybelteks as openbaring (van God) wat as vanselfsprekend aanvaar word en waarvan die betekenis net hoef getap te word. Die rol van die leser begin flouerig deurskemer, hoewel op 'n negatiewe wyse, want net een tipe leser word gelegitimeer, naamlik die 'kinderlik-gelowige' een wat op die ou end die Bybel in naief-realistiese terme lees. Wanneer hierdie soort lees bedreig word, word die leeswyse nie aan kritiese refleksie onderwerp nie, maar afgekamp met die finale argument dat die gewone lidmate nie verwar moet word nie. 
Die tydperk sedert 1970 kan gesien word as die ontplooiing en verfyning van die gedagtes van J.D. du Toit en W.J. Snyman soos dit veral na vore kom in die minimalisering van die menslike aspek by die beoefening van teologie en die gedagtes rondom die Bybel. 'n Mens soek verniet na' $n$ uitgewerkte antropologie by die teologiese besigwees van die jare sewentig-tagtig. Die mensbeskouing kan in een sin, na aanleiding van Vraag 8 van die Heidelbergse Kategismus, saamgevat word: "die mens is so verdorwe dat hy heeltemal onbekwaam is tot enige goed en geneig is tot alle kwaad". Die enigste manier waarop hierdie verdorwenheid oorwin kan word, is deur die wedergeboorte deur die Heilige Gees. Vandaar dan ook die klem op die Heilige Gees in die Gereformeerde teologiebeoefening.

Kontrole binne ' $n$ wetenskaplike teologiese opset is belangrik. Die fokus op metodes, modelle, taal en kenteorie is 'n poging om daardie leemte te vul. Juis die afwesigheid van 'n behoorlike kontroleerbare model veroorsaak dat die Bybel magies as Woord begin geld, sodat mens feitlik enige ding onder die son kan sê en jou op die Bybel beroep. As daar uitgegaan word van die algehele verdorwenheid van die mens, is 'n kontrole gebiedend noodsaaklik ten einde te bepaal wanneer die mens nie dalk' $n$ foutiewe Bybellees pleeg en agter die Heilige Gees gaan skuil om gesag aan sy dikwels foutiewe lesings te gee nie. 'n Duidelike verdiskontering van, onder andere, kenteoretiese vooronderstellings bied aan lesers of hoorders van teologiese argumente 'n kontrole waaraan waarheidsaansprake gemeet kan word.

Reeds in 1965 het wyle prof. Fanus du Toit (1965:77), seun van J.D. du Toit, gewaarsku teen tradisie wat hyna met die belydenis gelykgestel word, teen belydenisse wat met die Bybel gelykgestel word, teen tradisies wat uiteindelik as belydenis met die Skrif gelykgestel word en teen wysgerige krummels wat uitgestrooi word en uiteindelik hulle weg in die kerke vind en selfs as toets vir regsinnigheid aangelê word. Hy was bang dat die tradisie as 'n leer naas die belydenis begin funksioneer (1965:76).

Die probleem vandag in die GKSA lê nie in die uitstrooi van wysgerige krummels nie daarsonder kan mens nie jou denke oor dinge in 'n raamwerk giet nie omdat 'n mens dit saam met jou teologiese moedersmelk kry. Die probleem kom egter wanneer daar nie cor daardie krummels gereflekteer word nie en uiteindelik as 'openbaring' uit die Skrif gehaal word en met gesag beklee word. Enige resepsie van die Bybel geskied binne 'n raamwerk van kenteorie, ' $n$ bepaalde gemeenskap en onderhewig aan 'n bepaalde ideologie. Die mens dra daardie raamwerk met hom saam en dit worl bepaal deur baie faktore. Die rol wat hierdie raamwerk speel in die interpretasie van die Bybel mak van die mens 'n skeppende leser. Dat 'n mens ' $n$ bepaalde raamwerk gebruik, behoort erken te word. Die mens het nie sy kreatiwiteit met dic sondeval verloor nie. Kreatiwiteit gaan wel met moeite gepaard - die moeite binne 'n teologiese wetenskap lè dalk daarin dat die skeppende alard van die mens blootgelê en erken behoort te word. 
wetenskap lè dalk daarin dat die skeppende aard van die mens blootgelè en erken behoort te word.

'n Ontkenning (of miskenning) van denkraamwerke hou die gevaar in dat bepaalde tradisionele denkstrukture wat hulle oorsprong in die filosofie het, ewe skielik uit die Bybel gepositiveer word en met daadwerklike openbaringsgesag beklee word. Is dit nie wat gebeur wanneer die mens in 'n minderwaardige posisie ten opsigte van die leesproses gestel word net sodat God meer vertoon word nie? Psalm 8 dig aan die mens ' $n$ heerlike posisie ten opsigte van die skepping toe. Daardie posisie behoort ten minste ten opsigte van 'n Gereformeerde lees van die Bybel in gedagte gehou word, anders word van die Bybel 'n afgod gemaak.

\section{BIBLIOGRAIFIE}

BLUMENBERG, H. 1964. Wirklichkeitsbegriff und Möglichkeit des Romans. (In JauB, H-R. red. Nachahmung und Illusion. München : Eidos Verlag. p. 9-27.)

BOTHA, J. 1990. Semcion. Inlciding tot aspekte van die interpretasic van dic Gricksc Nuwe Testament. Prctoria : NGKB 1988 (Edms) Bpk.

BRAUDE, W.G. \& KAPSTEIN, IJ. Iransl. 1981. The Lore of the School of Elijah. Philadelphia : The Jcwish Publication Socicty of America.

CANCIK, 11. 1970. Mylhische und hislorische Wahrheit. Inlerpretationen zu Texien der hethitischen, biblischen und gricchischen Historiographic. Stuttgart : Verlag Katholisches Bibelwerk.

COETZEE, C.F.C. 1989. Dic gesag van dic Bybel. Die Kenkblad :27-28. Feb. 22.

COETZEE, J.C. 1979. ' $n$ "Ou Bock in 'n nuwe wèreld, of 'n nuwe Boek in 'n ou wèreld"? In die Skriflig, 13(49):4-15.

COETZEE, J.C. 1981. Uit die Rektor se pen. Die Teologiese Skool, Potchelstroom - Teologie en diens van die Woord. Goule Kandelaar, 20:10-11.

COETZEE, J.C. 1982. Uil die Reklor se pen. Dic Woord van God, die Heilige Gees en tcologiese studie en navorsing. Goue Kandelaar, 21:8-9.

COETZEE, J.C. 1984. Die Skrif en die wetenskap: hermeneutiese rečls. (In Duvenagc, B. red. Welenskap en Woord. 'n Bundcl voordragic saamgestel deur die Departement Wetenskapsleer. PU vir CHO : Polchefstroom. p. 15-32.)

COETZEE, J.C., DE KLERK, B.J. \& FLOOR, L. 1980. Die hermeneuse van dic Skrif met die oog op hedendaagse kerklik-etiese vraagstukke. In die Skriflig, 14 (54):12-26.

COETZEE, P. . 1977. 'n Drie-dimensioncle fokus op die Teologiese Skool. Goue Kandelaar, 16:5-6.

COETZEE, P J. 1979. Dic Tcologiesc Skool 'n kosbare pand. Goue Kandelaar, 18:6-7.

D'ASSONVILLE, V.E. 1986. "Vivat schola, vivat religio" (Willem van Oranjc). Gouc Kandelaar, 25:6-7.

D'ASSONVILLE, V.E. 1989. Was hicrdie gecsle gevalle engele (duiwels)? Die Kerkblad :18-19. Maart 8.

DE BEER, H J.P. 1990. "Ek huiwer om dit le sẽ" en art. 53 KO. Die Kerkblad :30-31. Junie 6.

DEIST, F.E. 1988. "Gckontroleerde" eksegesc en/of "kreatiewe" uitleg. Henomide Teologiese Studies, 44(1):39-54.

DE WIN, X. 1980. Plato. Verzameld Werk, Derde decl: Alcibiades I, De Staat, De Staatsman, Critias. Ambo : Baarn.

DU TOIT, S. 1965. Tussen verstarring en verwarring. Tradisie-belydenisskrif. Ned Geref Teologiese Tydskif, 6:75-80.

DU TOIT, S. 1966. Excgesis and Philosophy. Biblical Essays. Proceedings of the $9 \mathrm{~h}$ mecting of Die OuTest amentiese Werkgemeenskap in Suid-Afrika. p. 62-71.

ELSE, G.F. 1986. Plato and Aristotlc on Poctry. Edited with Introduction and Notes by P. Burian. University of North Carolina Press : Chapel Hill. 
HOLTZ B.W. 1984. On Reading Jewish Texts. (In Holtz, B.W. ed. Back to the Sources: Reading the Classic Jewish Texts. New York : Summit Books. p. 11-30.)

JAUB, H-R. 1982. Ästhetische Erfahrung und literarische Hermeneutik. Frankfurt am Main : Suhrkamp.

KöHN, L. 1975. Der positivistische Ansatz. (In Hauff, J. et al., reds. Methodendiskussion. Arbeitsbuch zur Literaturwissenschaft. Band 1. Frankfurt am Main : Athenaum Fischer Taschenbuch Verlag. p. 29-100.)

KRUGER, G.J. 1991. Prof. Snyman sny 'n diep senuwee raak. Insig, Jun. 6.

KRüGER, P.P. 1991a. Is Allah God? Die Kerkblad :29. Febr. 13.

KRüGER, P.P. 1991b. Afgodery met die enige, ware God. Die Kerkblad :28-29. Maart 13.

LATEGAN, B. 1988. Why so Few Converts to New Paradigms in Theology? (In Mouton, J., Van Aarde, A.G. \& Vorster, W.S. eds. Paradigms and Progress in Theology. HSRC Studies in Research Methodology. Vol 5. Pretoria : Human Sciences Research Council. p. 65-78.)

LION-CACHET, F.N. 1984. 'n Kritiese beskouing van Deist se "ABC van Bybeluilleg". In die Skriflig, 18(69):38-51,

LION-CACHET, F.N. 1985. Antwoord op Deist se kritiek. In die Sknjlig, 19(75):45-48.

LION-CACHET, F.N. 1986. Dic Gereformeerde beoefening van die Ou-Testamentiese Wetenskap aan die Teologiese Skool te Potchefstroom. Goue Kandeloar, 25:14-16.

METZLER, D. 1973. Bilderstürme und Bilderfeindlichkeit in der Antike. (In Warnke, M., red. Bildersturm. Die Zerstōrung des Kunstwerks. Carl Hanser : München. p. 14-29.)

SCHUTTE, H.J. 1991. 'Suiwer' leer nie genoeg! Insig :6-7. Jun.

SHOREY, P. 1938. Platonism. Ancient and Modern. University of California Press : Berkeley.

SNYMAN, J.J. 1991. Doppers se dilemma. 'Stem van Potch' is stil. Insig:10-12. Mei.

STUMPF, S.E. 1975. Socrates to Sartre. A History of Philosophy. Second Edition. McGraw-Hill Book Company : New York.

TIGERSTEDT, E.N. 1974. The Decline and Fall of the Neoplatonic Interpretation of Plato. Commentationes Humanorum Litterarum 52. Societas Scientiarum Fennica: Helsinki.

VAN DER LINDE, I. 1991. Potchefstroom se Doppers - geisoleerd of benepe? Vrye Weekblad :10. Jan. 25.

VAN DER WALT, T. 1973. Kom en gaan op die Teologiese Skool. Goue Kandelaar, 12:9-10.

VAN HUYSSTEEN, W. 1987. The Realism of the Text. A Perspective on Biblical Authority. Pretoria : Unisa.

VAN RENSBURG, J.J.J. 1988. Christus se prediking aan die geeste in dic gevangenis - 1 Pt. 3:19. (In Coetzee, J.C. red. Koninkryk, Gees en Woord. Huldigingsbundel aan prof. Lambertus Floor by sy emeritaal as profesoor in Nuwe Testament aan die Teologiese Skool, Potchefstroom en die Fakulteit Teologie van die Potchefstroomse Universiteit vir Christelike Hoër Onderwys. Pretoria : NG Kerkboekhamdel.)

VAN RENSBURG, J.J.J. 1989. Verweer teen klag van openbare valse leer en openbare skeurmakery. Ongepubliseerd.

VAN TIL, C. 1955. The Defense of Faith. Philadelphia : The Presbyterian and Reformed Publishing Co.

VENTER, J.L. 1989. Die verhouding tussen kateder en kanscl: dic implikasies wat dit vir die teologie en die prediking inhou. (In Coetzee, J.C. red. Koninkryk Gees en Woord. Huldigingsbundel aan prof dr Lambertus Floor by sy emiritaat as professor in Nuwe Testament aan die Teologiese Skool, Potchefstroom en die Fakulteit Teologie van die Potchefstroomse Universiteit vir Christelike Hocer Onderwys. Pretoria : NG Kerkboekhandel. p. 163-178.)

VORSTER, J.N. 1988. The Use of Scripture in Fundamentalism. (In Mouton, J., Van Aarde, A.G. \& Vorster, W.S. eds. Paradigms and Progress in Theology. HSRC Studies in Research Methodology. Vol 5. Pretoria : Human Sciences Research Council. p. 155-175.) 